\title{
PENERAPAN MODEL PEMBELAJARAN BERBASIS INKUIRI UNTUK MEMBERDAYAKAN KETERAMPILAN KERJA ILMIAH DAN PEMAHAMAN KONSEP MAHASISWA
}

\author{
Lukman Hadi $^{(1)}$, Rahmat Rasmawan ${ }^{(1)}$ \\ ${ }^{(1)}$ Dosen Program Studi Pendidikan Kimia FKIP Untan \\ Email: rahmatfkip@gmail.com
}

\begin{abstract}
The aim of this study was to describe conceptual understanding and sciences process skills of students through inquiry-based learning. The study was conducted in form of one group pretest-posttest design. Thirty five students of chemistry education program of fkip untan participated. Result showed difference of sciences process skills and conceptual understanding of students, before and after inquiry basedlearning. Sciences process skills of students improved from 0\% to $52 \%$ and $16 \%$ to $40 \%$ on very skilled and skilled categories respectively. Furthermore, conceptual understanding of students improved from $15 \%$ to $89 \%$. To conclude, inquiry-based learning was able to improve conceptual understanding and sciences process skills of students.
\end{abstract}

Key words: Inquiry-based learning, conceptual understanding, sciences process skills.

Program studi pendidikan kimia FKIP Universitas Tanjungpura bertugas mempersiapkan calon guru kimia yang unggul baik dalam merancang proses pembelajaran dan pemahaman konsep mata pelajaran kimia jenjang SMP dan SMA. Sebagai calon guru, mahasiswa pendidikan kimia FKIP Untan harus memiliki kompetensi pedagogik, kepribadian, sosial dan kompetensi professional (UU No 14 Tahun 2005 tentang Guru dan Dosen). Dari keempat kompetensi tersebut, kompetensi professional memegang peranan yang cukup penting karena setiap guru harus dapat menguasai materi pembelajaran secara luas dan mendalam yang memungkinkannya membimbing siswa memenuhi standar kompetensi yang ditetapkan dalam Standar Nasional Pendidikan.
Mahasiswa calon guru bidang studi kimia harus memiliki pola pikir sebagaimana ilmu kimia ditemukan dan tujuan ilmu kimia diajarkan di sekolah agar kompetensi professional dapat dikuasai dengan baik. Menurut Bretz (2008), ilmu kimia memiliki dua karakteristik yaitu kimia sebagai produk (ilmu kimia yang berkaitan dengan sejumlah konsep, teori, hukum dan postulat yang menyusun gejala alam) dan kimia sebagai proses (merupakan kerja ilmiah yang teratur dan terorganisis sehingga dihasilkan temuan-temuan baru dalam bidang ilmu kimia). Tujuan diajarkannya mata pelajaran kimia di SMA/MA menekankan bahwa dalam proses pembelajaran harus dapat menumbuhkan kemampuan berpikir, bekerja dan bersikap ilmiah serta kemampuan berkomunikasi sebagai 
aspek penting dari kecakapan hidup (Kemendikbud, 2013). Dengan demikian, mahasiswa calon guru kimia harus dapat menguasai materi kimia yang luas dan mendalam serta keterampilan kerja ilmiah sebagai bekal mereka kelak menjadi calon guru kimia yang profesional.

Hasil yang diperoleh dalam bidang sains (khususnya kimia) belum menunjukkan hasil yang memuaskan. PISA (Programme for International Student Assessment) menunjukkan kemampuan literasi sains dan keterampilan berpikir tingkat tinggi (High Order Thinking) mahasiswa Indonesia menunjukkan penurunan dari tahun ke tahun, yaitu pada tahun 2003 berada pada rangking 38 dari 40 negara peserta, pada tahun 2006 menduduki peringkat 50 dari 57 negara. Hal ini mengindikasikan bahwa proses pembelajaran yang dilakukan belum dapat mengembangkan keterampilan berpikir mahasiswa serta keterampilan kerja ilmiah sebagai dasar kemampuan literasi sains.

Hasil penelitian yang dilakukan Rasmawan, R (2015) tentang keterampilan berpikir dan kerja ilmiah siswa mendapatkan hasil bahwa keterampilan kerja ilmiah mahasiswa FKIP Untan semester V berada pada kategori kurang terampil. Hasil tersebut disajikan pada Tabel 1 .

Tabel 1. Keterampilan kerja ilmiah mahasiswa semester V Prodi Pendidikan Kimia FKIP Untan.

\begin{tabular}{clcc}
\hline No & \multicolumn{1}{c}{ Deskripsi } & $\begin{array}{c}\text { Rerata } \\
\text { Skor }\end{array}$ & Kategori \\
\hline 1 & $\begin{array}{l}\text { Mengidentifikasi komponen dari desain atau prosedur } \\
\text { eksperimen (variabel respon, manipulasi, dan kontrol) }\end{array}$ & 1,76 & TT \\
2 & $\begin{array}{l}\text { Menerjemahkan data yang diberikan ke dalam bentuk grafik } \\
\text { Menganalisi data yang disajikan dalam grafik, angka, atau } \\
\text { tabel. }\end{array}$ & KT \\
4 & $\begin{array}{l}\text { Memilih informasi yang diperlukan untuk merumuskan } \\
\text { hipotesis }\end{array}$ & KT \\
5 & $\begin{array}{l}\text { Mengembangkan prosedur baru untuk mendapatkan } \\
\text { informasi baru }\end{array}$ & TT \\
6 & $\begin{array}{l}\text { Menggunakan atau memperluas informasi yang diberikan } \\
\text { terhadap konteks yang lebih luas atau berbeda (generalisasi) } \\
7\end{array}$ & TT \\
$\begin{array}{l}\text { Memilih informasi yang diperlukan untuk menarik } \\
\text { kesimpulan }\end{array}$ & 1,76 & KT \\
\hline Ketergan
\end{tabular}

Keterangan:

TT : Tidak Terampil

KT : Kurang Terampil

Berdasarkan hasil observasi pada saat pembelajaran dan praktikum, wawancara dosen dan mahasiswa prodi pendidikan kimia FKIP Untan dapat disimpulkan ke dalam beberapa hal, yaitu: a) Proses pembelajaran yang sering dilakukan dosen dalam pembelajaran kimia adalah menyampaikan konsep yang harus dikuasai mahasiswa sehingga terbentuk pola pikir di mahasiswa bahwa belajar kimia cukup dengan menghafal dan latihan soal (Jazadi, 2005), b) Dosen jarang mengaitkan materi pelajaran kimia dengan kehidupan sehari-hari mahasiswa 
sehingga terbentuk pola pikir bahwa materi kimia tidak memiliki keterkaitan langsung dengan kehidupan mereka (Holbrok, 2005), c) Bentuk tes yang biasa dilatihkan dosen adalah penyelesaian masalah algoritmik yang biasa dijawab melalui suatu prosedur yang telah baku atau keahlian kognitif tingkat rendah (Zoller, et al.,1995).dan d) Praktikum yang dilakukan hanya bersifat verifikatif, yaitu hanya sekedar membuktikan suatu hukum atau teori yang telah dipelajari dan bukan pada proses pencarian pengetahuan.

Proses pembelajaran yang hanya menyampaikan konsep yang harus dikuasai, jarang mengaitkan materi pelajaran kimia dengan kehidupan sehari-hari, bentuk tes yang memiliki kecenderungan hanya biasa penyelesaian masalah algoritmik yang biasa dijawab melalui suatu prosedur yang telah baku dan bentuk praktikum yang bersifat verifikatif ternyata tidak dapat membentuk pemahaman konsep dan keterampilan kerja ilmiah mahasiswa. Keterampilan kerja ilmiah dan dan pemahaman konsep yang luas dan mendalam adalah keterampilan yang harus dikuasai mahasiswa agar menjadi calon guru yang profesional.

Pola pembelajaran kimia yang selama ini dilakukan perlu segera diperbaiki. Hendaknya pembelajaran kimia dirancang dan memperhatikan tujuan, karakteristik materi yang diajarkan, kemampuan mahasiswa dan sumber belajar yang tersedia. Mahasiswa diberi kesempatan untuk menggali pemahaman, mengembangkan kemampuan berpikir dan kerja ilmiah, terutama dalam hal penyelesaian masalah. Dengan demikian, dosen harus memberikan kesempatan kepada mahasiswa untuk dapat memahami, merancang, memecahkan masalah, mengetahui bagaimana cara dan mengapa melakukan, menganalisis, memonitor, mengevaluasi dan mengembangkan pemahaman konsepnya (Permendiknas nomor 41 tahun 2007).

Salah satu model pembelajaran yang dapat diterapkan adalah model pembelajaran berbasis inkuiri. Menurut National Research Council (2000) inkuiri merupakan suatu kegiatan yang melibatkan mahasiswa melakukan pengamatan, mengajukan pertanyaan, memeriksa buku-buku dan sumber informasi lain, merencanakan penyelidikan, meninjau hasil eksperimen, menganalisis atau menafsirkan data, mengusulkan jawaban terhadap data, memberikan penjelasan terhadap prediksi dan mengkomunikasikan hasil. Sejalan dengan itu, Arrends (2012) menyatakan bahwa model inkuri adalah suatu proses pembelajaran yang menempatkan dosesn untuk memfasilitasi tahapantahapan proses penyelidikan dan membantu mahasiswa untuk merefleksi proses pemikiran mereka.

Model pembelajaran berbasis inkuiri berawal dari masalah dan kemudian menyelesaikan masalah tersebut melalui penyelidikan ilmiah. Proses penyelidikan ilmiah merupakan operasi mental yang kompleks, terdiri dari banyak komponen-komponen yang saling terkait (Carin, 1997). Dalam proses penyelidikan, mahasiswa dituntut untuk menggunakan keterampilanketerampilan dasar proses sains, antara lain: pengamatan, pengukuran, perhitungan, perencanaan 
eksperimen, melakukan eksperimen, perumusan hipotesis, penentuan variabel, perumusan definisi operasional variabel, pembuatan tabel data, pembuatan grafik, penginterprestasikan data, penarikan kesimpulan dan mempresentasikan hasil (Mohamad Nur, 2011).

Proses pembelajaran berbasis inkuiri memiliki hubungan secara langsung dengan aktivitas kerja ilmiah. PISA (2006) menyatakan setidaknya ada lima keterkaitan antara model inkuiri dengan keterampilan kerja ilmiah, yaitu:

1. Mengenal pertanyaan ilmiah, yaitu pertanyaan yang dapat diselidiki secara ilmiah, seperti mengidentifikasi pertanyaan yang dapat dijawab oleh sains.

2. Mengidentifikasi bukti yang diperlukan dalam penyelidikan ilmiah. Proses ini melibatkan identifikasi atau pengajuan bukti yang diperlukan untuk menjawab pertanyaan dalam suatu penyelidikan sains atau prosedur yang diperlukan untuk memperoleh bukti itu.

3. Menarik dan mengevaluasi kesimpulan. Proses ini melibatkan kemampuan menghubungkan kesimpulan dengan bukti yang mendasari atau seharusnya mendasari kesimpulan itu.

4. Mengkomunikasikan kesimpulan yang valid, yaitu mengungkapkan secara tepat kesimpulan yang ditarik dari bukti yang tersedia.

5. Mendemonstrasikan pemahaman terhadap konsep-konsep sains, yaitu kemampuan menggunakan konsep-konsep dalam situasi yang berbeda dari apa yang telah dipelajarinya.
Model pembelajaran berbasis inkuiri secara langsung dapat meningkatkan pemahaman konsep mahasiswa. Fiedel (2008) menyatakan bahwa model pembelajaran berbasis inkuiri mendorong siswa untuk membuat keputusan dan memecahkan masalah yang dihadapi dengan menggunakan konsep-konsep yang dianggapnya benar, kemudian menguji konsepkonsep tersebut lewat penyelidikan sehingga terjadi proses asimilasi pengetahuan. Unver dan Arabacioglu (2011) menyatakan bahwa model pembelajaran berbasis penyelidikan dapat mempengaruhi kreativitas dan kecerdasan dalam mengelolah pemikiran dan meningkatkan kemampuan literasi sains, pengetahuan yang dipelajari, mengembangkan keterampilan berpikir kritis dan keterampilan proses sains, serta menyelaraskan tentang pengetahuan konseptual dan kemampuan prosedural. Yadav dan Mishra (2013) menyatakan proses penyelidikan yang diintegrasikan dengan kerja laboratorium akan memberikan kesempatan kepada peserta didik untuk berinteraksi langsung dengan subjek materi atau konsep yang dipelajari sehingga dapat membentuk pemahaman yang utuh tentang konsep tersebut.

Berdasarkan uraian di atas
maka peneliti tertarik untuk menerapkan model pembelajaran berbasis inkuiri untuk meningkatkan pemahaman konsep dan keterampilan kerja ilmiah mahasiswa. Keterampilan kerja ilmiah merujuk pada kemampuan untuk menyelesaikan msalah yang dihadapi dengan cara atau urutan yang sistematis, dimulai dari menentukan 
masalah, merumuskan prediksi, merencanakan dan melaksanakan percobaan atau penyelidikan, serta mengkomunikasikan hasil yang diperoleh (National Research Council, 2000). Pemahaman konsep adalah mengkontruksi makna dari konsep yang dipelajari kemudian menerapkan, menganalisis, serta mengevaluasi suatu masalah berdasarkan konsep yang dipahaminya (Anderson, 2001).

Keterampilan kerja ilmiah dalam penelitian ini adalah rangkaian kerja yang sistematis yang saling berhubungan dengan delapan indikator, yaitu adalah menentukan masalah, merumuskan hipotesis, merumuskan variabel penelitian, merumuskan definisi operasional variabel, melakukan percobaan, mengkomunikasikan data dalam bentuk tabel atau grafik, menganalisis data dan merumuskan kesimpulan. Pemahaman konsep dalam penelitian ini adalah skor yang diperoleh mahasiswa dalam menyelesaikan masalah dalam bentuk soal tes dan dikatakan memiliki pemahaman konsep yang benar jika memperoleh skor proporsi jawaban minimal 70 .

Konsep yang akan diajarkan dalam penelitian ini adalah asam basa, yang meliputi pengertian asam basa, $\mathrm{pH}$ larutan, dan $\mathrm{pH}$ campuran asam basa. Dipilihnya konsep asam basa tersebut dikarenakan pada konsep tersebut memungkinkan mahasiswa melakukan penyelidikan yang mendalam tentang jenis-jenis larutan asam basa yang sering dijumpai dalam kehidupan sehari-hari serta memprediksi derajat keasaman dari campuran larutan yang bersifat asam dan basa.
METODE

Bentuk penelitian ini adalah Pree Eksperimental dengan rancangan One Group Pretes Postest Design. Subjek penelitian adalah mahasiswa Program Studi Pendidikan Kimia mempelajari materi asam dan basa pada mata kuliah Kimia Dasar 2 yang berjumlah 35 mahasiswa. Sebelum dilakukan pembelajaran dengan model berbasis inkuiri, terlebih dahulu diberikan pretes dengan tujuan untuk melihat kemampuan awal mahasiswa tentang keterampilan kerja ilmiah dan pemahaman konsep. Selanjutnya mahasiswa tersebut diberi perlakuan, yaitu dalam proses pembelajarannya diterapkan model pembelajaran berbasis inkuiri. Setelah dilakukan proses pembelajaran, selanjutnya mahasiswa diberi postest dengan tujuan untuk melihat kemampuan mahasiswa setelah menerima pembelajaran model berbasis inkuiri.

Alat pengumpul data dalam penelitian ini adalah tes keterampilan kerja ilmiah dan pemahaman konsep. Tes keterampilan kerja ilmiah digunakan untuk mengukur keterampilan kerja ilmiah mahasiswa dengan bentuk tes Performance Assessment dengan menggunakan rubrik penskoran pada tiap-tiap indikator yang diujikan. Tes pemahaman konsep digunakan untuk mengukur sejauh mana pemahaman konsep mahasiswa pada materi asam basa dengan menggunakan soal tes tertulis dalam bentuk essay.

Sebelum digunakan, terlebih dahulu divalidasi oleh pakar pendidikan kimia. Hasil validasi menunjukkan bahwa tes keterampilan kerja ilmiah dan pemahaman konsep telah sesuai dengan indikator yang 
ditentukan. Bahasa yang digunakan dalam tes sesuai dengan kaedah Bahasa Indonesia, tidak menimbulkan makna ganda dan mudah dipahami maksudnya. berdasarkan hasil validasi maka alat pengumpul data (tes keterampilan kerja ilmiah dan pemahaman konsep) telah valid dan layak digunakan dalam penelitian.

Data tes keterampilan kerja ilmiah selanjutnya ditentukan kategori keterampilan kerja ilmiah dengan rumusan sebagai berikut:

Nilai $=\frac{\text { Jumlah Skor }}{\text { Jumlah Skor Maksimal }} x 100 \%$ Selanjutnya nilai yang diperoleh disesuaikan dengan kriteria dari Paul and Elder (2008) berikut ini:

Tabel 2. Kriteria keterampilan kerja ilmiah.

\begin{tabular}{ccl}
\hline No & Nilai & \multicolumn{1}{c}{ Kategori } \\
\hline 1 & $1-24$ & Tidak Terampil \\
2 & $25-49$ & Kurang Terampil \\
3 & $50-74$ & Terampil \\
4 & $75-100$ & Sangat Terampil \\
\hline
\end{tabular}

Nilai keterampilan kerja ilmiah pada masing-masing indikator ditentukan dengan rumus berikut:

Nilai $=\frac{\text { total skor indikator }}{\text { skor maksimal } \mathrm{x} \text { jumlah mahasiswa }} \times 100 \%$

Data tes pemahaman konsep mahasiswa selanjutnya ditentukan ketuntasannya dengan rumusan sebagai berikut:

Proporsi $=\frac{\text { Skor yang diperoleh }}{\text { Skor total }} \times 100 \%$

Mahasiswa dikatakan memiliki pemahaman konsep apabila memperoleh nilai proporsi jawaban lebih besar atau sama dengan 70 .

Nilai pemahaman konsep mahasiswa pada masing-masing indikator ditentukan dengan rumusan sebgai berikut:

Nilai $=\frac{\text { total skor indikator }}{\text { skor maksimal } \times \sum \text { mahasiswa }} \times 100 \%$
Selanjutnya untuk mengetahui ada tidaknya perbedaan keterampilan kerja ilmiah mahasiswa dan pemahaman konsep mahasiswa sebelum dan sesudah pembelajaran dilakukan maka dilakukan uji statistik. Pada tes keterampilan kerja ilmiah, langkah pertama menentukan normalitas data pretes dan postest. Jika kedua data berdistribusi normal, maka dilakukan uji statistik $t$ sampel dependent dengan menggunakan program SPSS. Jika salah satu atau kedua data pretes dan postest tidak berdistribusi normal, maka dilakukan uji nonparametrik yaitu uji Wilcoxson.

Hal yang sama juga dilakukan pada tes pemahaman konsep. langkah pertama menentukan normalitas data pretes dan postest. Jika kedua data berdistribusi normal, maka dilakukan uji statistik $t$ sampel dependent dengan menggunakan program SPSS. Jika salah satu atau kedua data pretes dan postest tidak berdistribusi normal, maka dilakukan uji nonparametrik yaitu uji Wilcoxson.

\section{HASIL DAN PEMBAHASAN} 1. Keterampilan Kerja Ilmiah
Mahasiswa

Keterampilan kerja ilmiah mahasiswa sebelum pembelajaran dapat diketahui dari data pretes dan keterampilan kerja ilmiah mahasiswa setelah pembelajaran dapat diketahui dari data postest. Hasil yang diperoleh (Gambar 1) menunjukkan bahwa keterampilan kerja ilmiah pada saat postest lebih baik dibandingkan dengan pretes. Pada postest sebagaian besar mahasiswa berada pada kategori terampil dan sangat terampil sedangkan pada pretest sebagian 
besar mahasiswa berada pada kategori kurang dan tidak terampil.

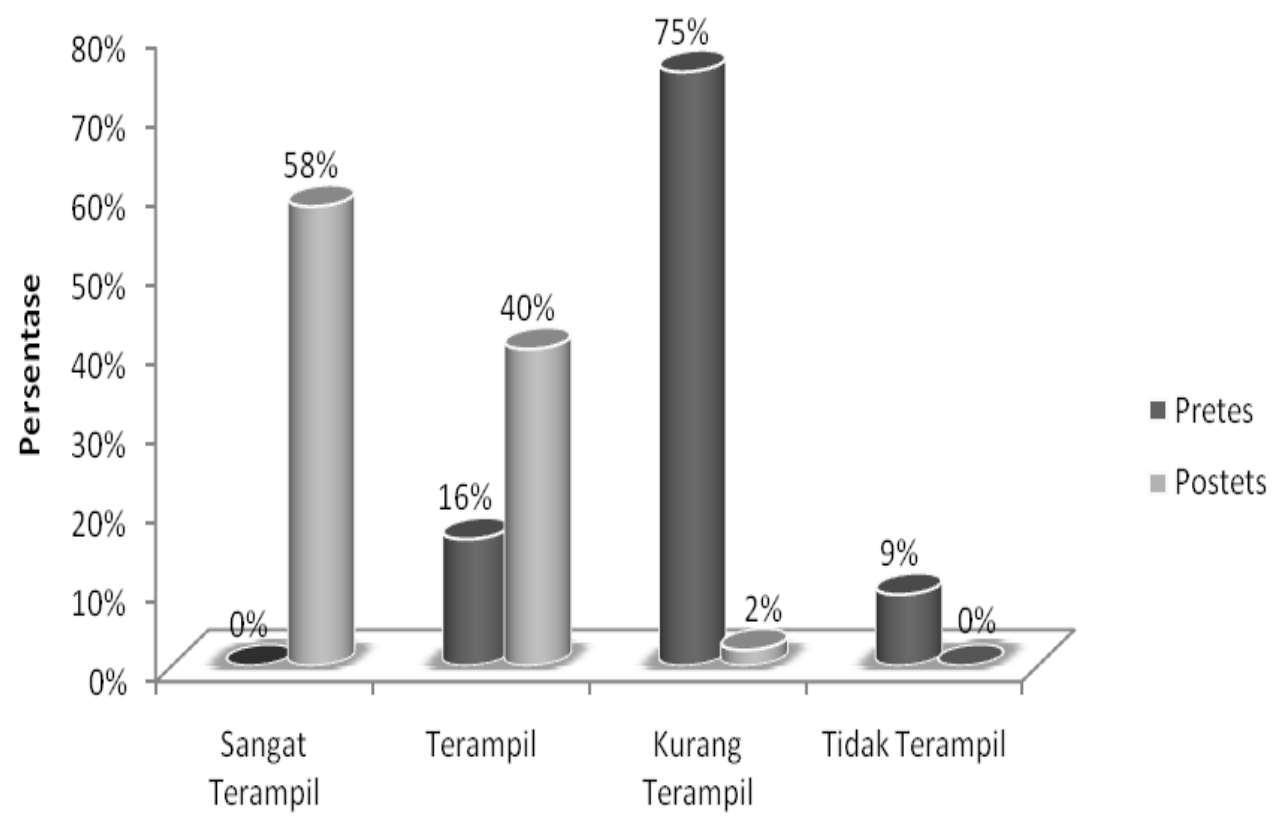

Kategori Keterampilan Kerja IImiah Mahasiswa

Gambar 1. Kategori keterampilan kerja ilmiah mahasiswa.

Dilihat dari indikator tes keterampilan kerja ilmiah maka dapat ditentukan nilai rata-rata keterampilan kerja ilmiah per indikator. Hasil yang diperoleh (Gambar 2) menunjukkan bahwa setiap indikator keterampilan kerja ilmiah mahasiswa pada postest lebih tinggi dibandingkan dengan postest. Hal ini mengindikasikan bahwa proses pembelajaran dengan model inkuiri dapat meningkatkan keterampilan kerja ilmiah mahasiswa.

Untuk melihat ada tidaknya perbedaan keterampilan kerja ilmiah mahasiswa sebelum dan sesudah diajar dengan model pembelajaran berbasis inkuiri maka dilakukan uji statistik. Karena data pretes dan postets berdistribusi normal, maka selanjutnya dilakukan uji statistik $\mathrm{T}$ sampel dependend dengan menggunakan software SPSS. Hasil yang diperoleh (Tabel 2) didapatkan nilai Sig.(2-tailed) $0,000<0,05$ sehingga dapat disimpulkan terdapat perbedaan kemampuan awal dan akhir keterampilan kerja ilmiah mahasiswa setelah diajar dengan model inkuiri. 


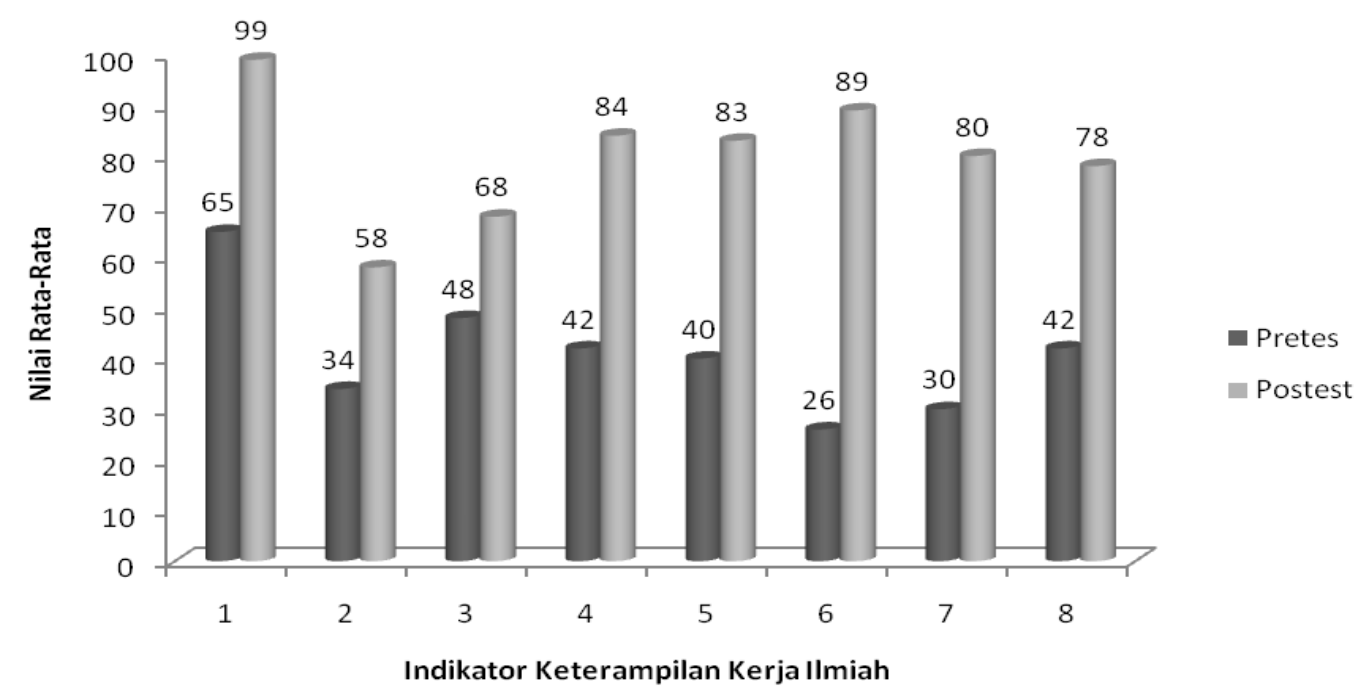

Keterangan

Indikator 1: Merumuskan Masalah, Indikator 2 : Menerapkan Konsep, Indikator 3: Merumuskan Hipotesis, Indikator 4: Merumuskan Variabel Percobaan, Indikator 5: Merumuskan Definisi Operasional Variabel, Indikator 6: Mengolah Data, Indikator 7: Menganalisis Data, Indikator 8 : Merumuskan Kesimpulan

Gambar 2. Nilai rata-rata indikator keterampilan kerja ilmiah.

Tabel 3. Uji T sampel dependend perets dan postest keterampilan kerja ilmiah.

Paired Samples Test

\begin{tabular}{|c|c|c|c|c|c|c|c|c|c|}
\hline & \multicolumn{5}{|c|}{ Paired Differences } & \multirow[b]{3}{*}{$\mathrm{t}$} & \multirow[b]{3}{*}{$\mathrm{df}$} & \multirow{3}{*}{$\begin{array}{l}\text { Sig. (2- } \\
\text { tailed) }\end{array}$} \\
\hline & & \multirow[b]{2}{*}{ Mean } & \multirow{2}{*}{$\begin{array}{c}\text { Std. } \\
\text { Deviatio } \\
\mathrm{n}\end{array}$} & \multirow{2}{*}{$\begin{array}{l}\text { Std. } \\
\text { Error } \\
\text { Mean } \\
\end{array}$} & \multicolumn{2}{|c|}{$\begin{array}{l}95 \% \text { Confidence } \\
\text { Interval of the } \\
\text { Difference } \\
\end{array}$} & & & \\
\hline & & & & & Lower & Upper & & & \\
\hline Pair & $\begin{array}{l}\text { Pretes_ } \\
\text { Postest }\end{array}$ & $-11,813$ & 3,914 & ,692 & $-13,224$ & $-10,401$ & $-17,073$ & 32 & ,000 \\
\hline
\end{tabular}

Terdapatnya perbedaan keterampilan kerja ilmiah sebelum dan sesudah pembelajaran dengan model inkuiri disebabkan karena pada fase-fase model inkuiri terdapat aktivitas mahasiswa mengembangkan keterampilan kerja ilmiah yang terangkum dalam Lembar Kerja Mahasiswa (LKM). Fase satu model inkuiri, mahasiswa dihadapkan pada suatu fenomena yang ada di lingkungan sehari-hari mereka dalam bentuk kasus yang tertuang dalam LKM. Tujuan diberikan kasus yang ada dilingkungan sehari-hari agar memotivasi mahasiswa menyelesaikannya dengan cara penyelidikan. Menurut Arrend (2012) menyatakan bahwa kasus yang paling dekat dengan kehidupan sehari-hari peserta didik dapat memotivasi belajar mereka untuk menyelesaikan masalah tersebut lewat cara penyelidikan.

Fase dua model inkuiri melibatkan mahasiswa merumuskan masalah dari kasus yang diberikan yang diberikan pada fase satu yaitu 
bagian kasus dalam kehidupan seharihari mahasiswa. Keterampilan kerja ilmiah yang dilatih pada fase dua ini adalah keterampilan merumuskan masalah. Pada fase ini, mahasiswa dapat menentukan masalah utama yang akan dipecahkan. Fase tiga mahasiswa diminta memilih informasi-informasi relevan yang terkait dengan masalah yang akan diselidiki dan selanjutnya digunakan sebagai dasar merumuskan hipotesis. Pada fase ini, mahasiswa harus dapat mengumpulkan informasi-informasi yang berkaitan langsung dengan masalah yang akan diselidiki dan membuang informasi-informasi lain yang tidak penting atau diluar dari masalah yang telah dirumuskan. Berdasarkan informasi tersebut, mahasiswa diminta merumuskan hipotesis yaitu jawaban sementara dari masalah yang dihadirkan. Dengan demikian keterampilan kerja ilmiah mahasiswa pada indikator merumuskan hipotesis dilatihkan dalam proses pembelajaran.

Fase empat, mahasiswa diminta untuk mencermati prosedur kerja yang diberikan dengan mengecek variabel kontrol, respon dan manipulasi serta definisi operasional variabel tersebut. Selanjutnya mahasiswa melakukan percobaan sesuai dengan prosedur kerja yang diberikan. Data yang diperoleh mahasiswa setelah melaksanakan ekspriment dicantumkan dalam bentuk tabel dan grafik. Selanjutnya mahasiswa diminta untuk menganalisis hasil percobaan mereka dengan cara menjawab seluruh pertanyaan-pertanyaan yang ada di dalam LKM. Dari aktivitas yang dilakukan mahasiswa dapat diketahui bahwa keterampilan kerja ilmiah mahasiswa dalam merumuskan variabel percobaan, merumuskan definisi operasional variabel serta mengkomunikasikan data dalam bentuk tabel atau grafik dilatihkan dalam proses pembelajaran.

Fase lima model inkuri melibatkan mahasiswa dalam merumuskan kesimpulan berdasarkan hasil yang diperoleh dari eksperiment. Dalam proses pembelajaran, keterampilan merumuskan kesimpulan diarahkan untuk menjawab masalah atau menerima atau menolak hipotesis berdasarkan hasil yang diperoleh dari proses penyelidikan. Dengan demikian keterampilan kerja ilmiah dalam merumuskan kesimpulan dilatihkan pada proses pembelajaran. Fase enam model inkuiri melibatkan mahasiswa melakukan refleksi dengan cara mempresentasikan hasil yang diperoleh di depan kelas. Pada kegiatan ini, masing-masing kelompok dapat mengecek kekurangan yang mereka lakukan dalam menyelesaikan masalah berdasarkan masukan dan saran dari kelompok lain dan dosen. Berdasarkan saran dan masukan tersebut, mahasiswa memperbaiki laporan hasil penyelidikan mereka.

Pembelajaran yang diawali dengan pemberian masalah yang akan diselidiki (Fase satu dan dua inkuiri) membuat mahasiswa mengatur cara belajarnya untuk menjawab masalah yang diberikan dengan berbagai cara seperti membaca buku untuk mengumpulkan informasi, bertanya kepada orang yang lebih ahli untuk menjawab masalah yang diberikan (Liliasari, 2010). Proses pembelajaran yang demikian dapat meningkatkan 
kualitas belajar siswa menjadi deep learning (Light and Cox, 2009).

2. Pemahaman Konsep Mahasiswa Pemahaman mahasiswa sebelum pembelajaran dapat diketahui dari data pretes dan pemahaman konsep mahasiswa setelah pembelajaran dapat diketahui dari data postest. Hasil yang diperoleh
(Gambar 3) menunjukkan bahwa pemahaman konsep siswa setelah pembelajaran lebih tinggi dibandingkan sebelum diajar dengan model inkuiri. Hasil ini mengindikasikan bahwa model inkuiri dapat meningkatkan pemahaman konsep mahasiswa.

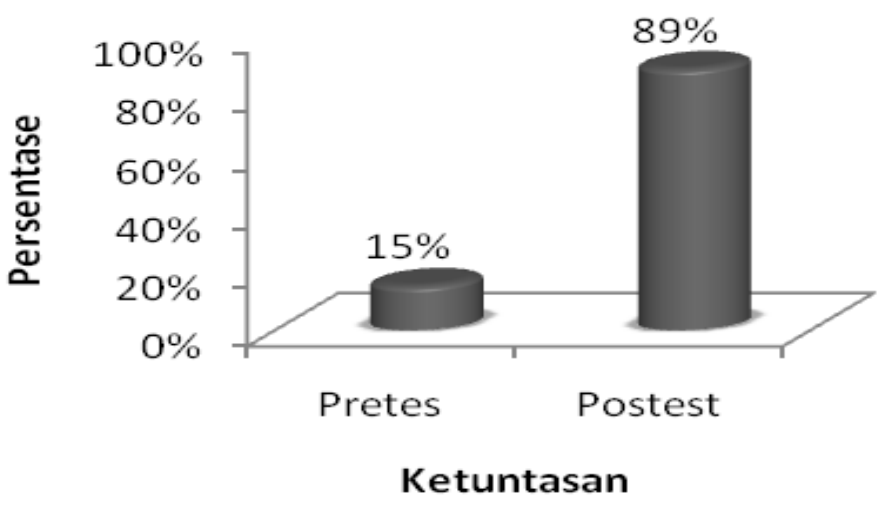

Gambar 3. Ketuntasan pemahaman konsep mahasiswa.

Dilihat dari indikator pemahaman konsep mahasiswa maka dapat ditentukan nilai rata-rata pemahaman konsep tiap indikator. Hasil yang diperoleh (Gambar 4) menunjukkan bahwa nilai setiap indikator pemahaman konsep mahasiswa pada postest lebih tinggi dibandingkan pretes. Hal ini mengindikasikan bahwa proses pembelajaran dengan model inkuiri dapat meningkatkan pemahaman konsep mahasiswa.

Untuk melihat ada tidaknya perbedaan pemahaman konsep mahasiswa sebelum dan sesudah diajar dengan model pembelajaran berbasis inkuiri maka dilakukan uji statistik. Karena data pretes dan postets berdistribusi normal, maka selanjutnya dilakukan uji statistik $\mathrm{T}$ sampel dependend dengan menggunakan software SPSS. Hasil yang diperoleh (Tabel 3) didapatkan nilai Sig.(2-tailed) $0,000<0,05$ sehingga dapat disimpulkan terdapat perbedaan kemampuan awal dan akhir pemahaman mahasiswa setelah diajar dengan model inkuiri. 


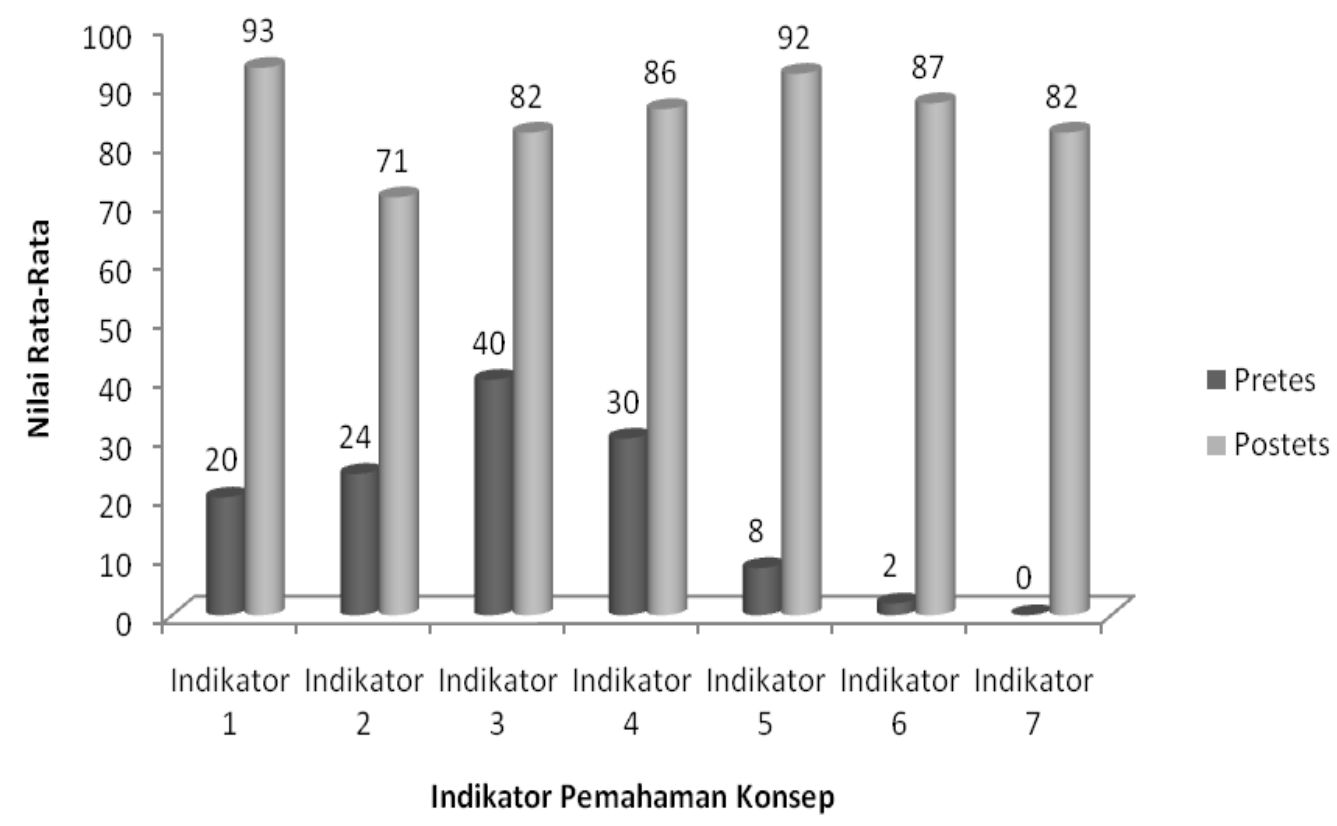

Keterangan:

Indikator 1: Menjelaskan sifat asam atau basa suatu larutan berdasarkan teori Bronsted-Lowry Indikator 2: Menjelaskan ciri-ciri larutan asam atau basa kuat Indikator 3: Menentukan pH larutan asam atau basa kuat

Indikator 4: Menentukan $\mathrm{pH}$ larutan asam atau basa lemah

Indikator 5: Menentukan nilai kesetimbangan asam atau basa berdasarkan $\mathrm{pH}$ dan konsentrasi larutan

Indikator 6: Menentukan $\mathrm{pH}$ campuran asam dan basa

Indikator 7: Membuat kurva titrasi asam basa

Gambar 4. Pretes dan postest pemahaman konsep tiap indikator.

Tabel 4. Uji T sampel dependend Data Perets dan Postest Pemahaman Konsep

Paired Samples Test

\begin{tabular}{|c|c|c|c|c|c|c|c|c|}
\hline & \multicolumn{5}{|c|}{ Paired Differences } & \multirow[b]{3}{*}{$\mathrm{t}$} & \multirow[b]{3}{*}{$\mathrm{df}$} & \multirow{3}{*}{$\begin{array}{l}\text { Sig. (2- } \\
\text { tailed) }\end{array}$} \\
\hline & \multirow[b]{2}{*}{ Mean } & \multirow{2}{*}{$\begin{array}{c}\text { Std. } \\
\text { Deviation }\end{array}$} & \multirow{2}{*}{$\begin{array}{c}\text { Std. } \\
\text { Error } \\
\text { Mean }\end{array}$} & \multicolumn{2}{|c|}{$\begin{array}{l}95 \% \text { Confidence } \\
\text { Interval of the } \\
\text { Difference }\end{array}$} & & & \\
\hline & & & & Lower & Upper & & & \\
\hline $\begin{aligned} \text { Pair } 1 & \text { Pretes_Pemahaman_Konsep - } \\
& \text { Postest_Pemahaman_Konsep }\end{aligned}$ & $-71,545$ & 9,138 & 1,591 & $-74,786$ & $-68,305$ & $-44,976$ & 32 & ,000 \\
\hline
\end{tabular}

Keberhasilan mahasiswa menguasai konsep disebabkan dalam proses pembelajaran, mahasiswa diberikan kesempatan mengumpulkan informasi yang relevan dan digunakan dalam merumuskan hiptesis pada fase tiga model inkuri serta membuktikan hipotesis yang dibuat dengan melakukan eksperimen. Menurut
Solso (2008) tahap awal pembentukan konsep adalah pada saat mahasiswa merumuskan hipotesis atau strategi yang akan digunakan dalam penyelesaian masalah dan berupaya menemukan sesuatu untuk mendukung hipotesis atau strategi yang akan digunakan tersebut. Sejalan dengan itu, Piaget 
menyatakan bahwa pembuktian secara aktif yang lakukan mahasiswa dapat mendorong siswa merumuskan pengetahuan baru dengan cara memodifikasi, menambahkan karakteristik serta memperbaiki konsep yang telah dipahami sebelumnya (Slavin. 2006).

Pemahaman konsep mahasiswa yang mengalami peningkatan dikarenakan mahasiswa diberikan kesempatan berinteraksi langsung antara konsep yang dipercainya dengan pembuktian secara langsung kebenaran konsep yang dipahaminya. Diberikannya kesempatan berinteraksi secara langsung antara konsep yang dipelajari dengan pembuktian secara langsung dapat membentuk pemahaman yang utuh dikarenakan mahasiswa dapat mengoreksi kebenaran konsep yang dikuasai dengan bukti percobaan yang didapatnya melalui penyelidikan (Yadav dan Mishra, 2013).

\section{SIMPULAN DAN SARAN}

Dari hasil penelitian yang telah dilakukan dapat disimpulkan bahwa terdapat perbedaan keterampilan kerja ilmiah dan pemahaman konsep mahasiswa sebelum dan sesudah diajar dengan model inkuiri. Keterampilan kerja ilmiah mahasiswa sebelum dan sesudah pembelajaran dengan model inkuri mengalami peningkatan pada kategori sangat terampil dan terampil berturut-turut $0 \%$ menjadi $52 \%$ dan $16 \%$ menjadi 40\%. Pemahaman konsep sebelum dan sesudah pembelajaran dengan model inkuiri mengalami peningkatan dari $15 \%$ menjadi $89 \%$ mahasiswa yang tuntas.

Saran yang dapat diberikan pada proses penilaian keterampilan kerja ilmiah adalah pembuatan rubrik penilaian keterampilan kerja ilmiah dibuat sejelas mungkin agar tidak terjadi kesalahan dalam proses penilaian. Hal ini perlu dilakukan karena jawaban pada tes keterampilan kerja ilmiah bersifat open ended dan jawaban bisa bervariasi. Dengan membuat point-point penting dari rubrik tersebut, maka dapat diperoleh hasil penilaian yang jelas tentang keterampilan kerja ilmiah mahasiswa.

\section{DAFTAR PUSTAKA}

Bretz, L. 2008. Chemistry in the National Science Education Standards 2nd Edition. New York: National Academic Press.

Carin, Arthur A. 1997. Teaching Modern Science, Seventh Edition. New Jersey: PrenticeHall Inc.

Fiedel. 2008. Overtly Teaching Critical Thinking And InquiryBased Learning: A Comparison Of Two Undergraduate Biotechnology Classed. Journal of Agricultural Education Volume 49 (1) hal $72-84$.

Kemendikbud. 2013. Kurikulum 2013, Kompetensi Dasar Jenjang Sekolah Menegah Atas (SMA)/Madrasah Aliyah (MA).

Liliasari. 2010. Inovasi Pembelajaran Sains Menuju Profesionalisme Guru. Makalah, disajikan dalam seminar nasional Peran Guru Sains dalam Era Globalisasi di Gorontalo.

Mohamad Nur. 2011. Modul Keterampilan-Keterampilan Proses Sains. Surabaya: PSMS Unesa.

National Research Council. 2000. Inquiry And The National Science Education Standards: A 
Guide for Teaching and Learning. New York: National Academic Press.

Paul dan Elder. 2008. The Thinker's Guide to Scientific Thought. Fundations For Critical Thinking Press.

Permendiknas nomor 41 tahun 2007. Standar Proses Untuk Jenjang Pendidikan Dasar dan Menengah. Jakarta. Menteri Pendidikan Nasional.

PISA. 2006. Analyses, Reflections, and Explanations. Ministry of Education Publication. Dapat diaskes di http://www.pisa2006.helsinki.fi/ files/PISA06_Analyses_Reflect ions_and_Explanations.pdf

Rasmawan, R. 2015. Deskripsi Keterampilan Berpikir Kritis, Berpikir Ilmiah, dan Metakognitif Mahasiswa Pendidikan Kimia FKIP Untan. Laporan Penelitian DIPA Fakultas FKIP Untan. Tidak dipublikasikan.

Slavin. 2006. Educational Psychology: Theory and
Practice Eight Edittion. Boston: Allyn \& Bacon.

Solso. 2008. Psikologi Kognitif, Edisi Kedelapan (terjemahan). Jakarta: Erlangga.

Unver and Arabacioglu. 2008. Overviews on Inquiry Based and Problem Based Learning Methods. Western Anatolia Journal of Education Sciences (WAJES) Hal 303 - 311.

Yadav dan Mishra. 2013. A Study of Impact of Laboratory Approach on Achievement and Process Skills in Science among is Standard Students. International Journal of Scientific and Research Publications, Vol 3 (1). Hal 8-14.

Zoller, et al (1995). Teaching, learning, evaluation and selfevaluation of HOCS in the process of learning chemistry. Proceedings of the $3^{\text {rd }}$ European Conference on Research in Chemical Education, September, hal 60-67. 